Journal of Extension Education

Vol. 28 No. 1, 2016

\title{
Technology Adoption Behaviour of Jasmine Growers - A Critical Analysis
}

\section{P. Bagya Janani ${ }^{1}$, R. Premavathi ${ }^{2}$ and D.Puthira Prathap ${ }^{3}$}

\begin{abstract}
Jasmine (Jasminum sambac) is one of the oldest fragrant flowers cultivated by man. The flower is used for various purposes viz. making garlands, bouquets, decorating hair of women, religious offerings etc. Scientific cultivation ofjasmine is one of the important prerequisites for increasing the production and productivity among the jasmine growers. The technology adoption of jasmine cultivation by the jasmine growers has not received the attention of both the extension functionaries of State Department of Horticulture and Agriculture to the required level and hence, the present study was undertaken with the objective to study the adoption behavior of jasmine growers in Tiurnelveli District. Vallioor block of Tirunelveli district in Tamil Nadu was selected purposively for the study based on more area under jasmine cultivation with a sample size of 120 . The respondents were selected based on proportionate random sampling method. The data were collected from each respondent through pre-tested interview schedule. The results of the study revealed that majority of the jasmine growers had adopted local variety (Ramanathapuram), pest management practices for blossom midge and bud worm, right time of harvest, application of inorganic fertilizers, water management, weed management and application of manure after pruning. One-third of the respondents had adopted the technologies like optimum spacing, application of FYM and root rot disease management. Based on the findings, the paper suggests concerted dissemination efforts by the change agents in the region, for improving jasmine productivity.
\end{abstract}

Keywords : Adoption and jasmine cultivation technology.

\section{INTRODUCTION}

The process of scientific in plantation crops. These endeavours improvement and technological changes in India are most often confined to achieve output expansion in food crops, oilseeds, sugars and fibres and to certain extent proved successful in stimulating the Indian economic growth. Concurrent of these developments, commercialization of farming is evidenced in certain other

1 -Rural Development Officer, Union Bank of India, Madurai, 2- Programme Coordinator, ICAR-KVK, Thirupathisaram, 3 - Principal Scientist (Agricultural Extension), ICAR - Sugarcane Breeding Institute, Coimbatore-7. 
crops like jasmine whose contribution to local and nation's economy is substantial.

Tamil Nadu is the leading producer of jasmine in the country with an annual production of 92951 tonnes and productivity of 8.75 tonnes per hectare from the cultivated area of 10623 ha (2011-12). The flowers produced in the state are being exported to the neighbouring countries such as Sri Lanka, Singapore, Malaysia and Middle East countries. The major jasmine producing districts of Tamil Nadu are Dindigul, Salem, Madurai, Tirunelveli, Virudhunagar and Trichy. Since the crop requires huge manpower for harvesting and other operations, only small farmers are cultivating the crop. Tirunelveli districts ranks first in area under jasmine cultivation with an area of 1267.25 ha (Season and crop report, 2011-12).

Adoption studies are important to assess the actual impact of agricultural research, to set research properties and to provide direction to the extension efforts.

In general, it is felt that the technology adoption of jasmine cultivation by the jasmine growers in Tirunelveli had not received the attention of both the extension functionaries of State Departments of Horticulture and Agriculture to it deserves. Micro studies on technology adoption behavior of today's jamine growers are rare. Hence, the present study was undertaken with the objective to study the extent of technology adoption behavior of Jasmine growers in Tirunelveli district.

\section{METHODOLOGY}

Tirunelveli district of Tamil Nadu was purposively selected based on more area under jasmine cultivation. Tirunelveli district consists of nineteen blocks, out of which Vallioor block was selected, as this block had more area under jasmine cultivation. In Vallioor block, jasmine was cultivated in an area of 390.46 ha during 2011-12. Altogether 120 jasmine growers were selected from three revenue villages based on proportionate random sampling method. Data were collected with the help of a well structured pre-tested interview schedule and analysed with suitable statistical techniques.

Table 1.Distribution of Jasmine Growers According to their Overall Adoption of Technologies

$(n=120)$

\begin{tabular}{|c|c|c|c|}
\hline S.No. & Extent of Adoption & Number & Percentage \\
\hline 1 & Low & 12 & 10.00 \\
\hline 2 & Medium & 102 & 85.00 \\
\hline 3 & High & 6 & 5.00 \\
\hline & Total & 120 & 100.00 \\
\hline
\end{tabular}




\section{FINDINGS AND DISCUSSION}

\section{Overall Adoption of Jasmine Cultivation Technologies}

The success and failure of a technology is ascertained only after assessing its impact over the farming community. The distribution of respondents according to their overall adoption of technologies is given in Table 1.

It could be inferred from the Table that more than four-fifths of jasmine growers $(85.00 \%)$ had medium level of adoption followed by low level (10.00\%) and high level $(5.00 \%)$ of adoption. It could be understood that most of the respondents possessed low to medium levels of adoption. This might be due to lack of awareness on critical technologies viz., spacing, FYM application, pruning, weed management and pest management. This finding is in accordance with that of Sivashankar and Shashidhar (2011)

The adoption behavior of identified jasmine cultivation technologies was studied and the results are presented in Table.2.

\section{Varieties Cultivated}

The varieties of jasmine are Single Morga, Double Morga, Iruvatchi and Ramanathapuram local. Among the jasmine varieties it was observed that 100 per cent of the reporters had adopted Ramanathapuram local variety.

From the findings it could be observed that Ramanathapuram local grows well in and around Vallioor block because of optimum climatic condition, red soil and saline water in Vallioor block

Table 2. Distribution of Respondents According to Their Adoption of Cultivation Technologies

\begin{tabular}{|c|l|c|c|c|c|}
\hline \multirow{2}{*}{ S1.No. } & \multirow{2}{*}{ Cultivation Technologies } & \multicolumn{2}{|c|}{ Adopted } & \multicolumn{2}{c|}{ Not - Adopted } \\
\cline { 2 - 6 } & & No. & $\%$ & No. & \% \\
\hline 1. & Varieties & & & & \\
\hline & Ramanathapuram Local & 120 & 100.00 & - & \\
\hline 2. & Main Field Practices & & & & \\
\hline & $\begin{array}{l}\text { Spacing of 1.25 m x 1.25 } \\
\text { m }\end{array}$ & 48 & 40.00 & 72 & 60.00 \\
\hline 3. & Water Management & & & & \\
\hline & $\begin{array}{l}\text { Irrigation at Weekly } \\
\text { interval }\end{array}$ & 98 & 81.67 & 22 & 18.33 \\
\hline
\end{tabular}




\begin{tabular}{|c|c|c|c|c|c|}
\hline 4. & $\begin{array}{l}\text { Integrated Nutrient } \\
\text { Management }\end{array}$ & & & & \\
\hline a. & FYM $10 \mathrm{Kg} /$ plant & 52 & 43.33 & 68 & 56.67 \\
\hline b. & NPK at 60:120:120 & 108 & 90.00 & 12 & 10.00 \\
\hline c. & After pruning & 120 & 100.00 & - & - \\
\hline d. & During June - July & 97 & 80.83 & 23 & 19.17 \\
\hline 5 & Weeding and Pruning & & & & \\
\hline a. & Weed management & 110 & 91.66 & 10 & 8.33 \\
\hline \multirow[t]{3}{*}{ b. } & Pruning & & & & \\
\hline & i) $50 \mathrm{~cm}$ height & 43 & 35.83 & 77 & 64.17 \\
\hline & $\begin{array}{l}\text { ii) Time : last week of } \\
\text { November }\end{array}$ & 105 & 87.50 & 15 & 12.50 \\
\hline 6 & $\begin{array}{l}\text { Plant Protection } \\
\text { Measures }\end{array}$ & & & & \\
\hline I. & $\begin{array}{l}\text { Pest Management } \\
\text { Practices followed for: }\end{array}$ & & & & \\
\hline a. & Bud worm & 120 & 100.00 & - & - \\
\hline b. & Blossom midge & 120 & 100.00 & - & - \\
\hline c. & Red spider mite & 86 & 71.67 & 34 & 28.33 \\
\hline $\mathrm{d}$. & Nematode & 17 & 14.67 & 103 & 85.33 \\
\hline II & $\begin{array}{l}\text { Disease Management } \\
\text { Pratices followed for }\end{array}$ & & & & \\
\hline a. & Root rot & 69 & 57.50 & 51 & 42.50 \\
\hline \multirow[t]{2}{*}{7.} & Harvesting & & & & \\
\hline & $\begin{array}{l}\text { At fully developed } \\
\text { unopened flower buds } \\
\text { stage }\end{array}$ & 120 & 100.00 & - & - \\
\hline
\end{tabular}


compared to other varieties. Apart from that, Ramanathapuram local is the ruling variety of jasmine in Tamil Nadu known for its fragrance and thick petals.

\section{Main Field Practices}

The main field practices were further classified into five sub areas namely spacing, water management, integrated nutrient management, weeding, pruning and plant protection measures.

\section{Spacing}

It could be inferred from the Table that two-fifths (40.00\%) of the jasmine growers adopted spacing of $1.25 \mathrm{~m}$ and the rest of the respondents (60.00\%) did not adopt the recommended spacing. Regarding spacing, most of the farmers had the opinion that the recommended spacing is not sufficient to carryout the certain field operations like irrigation, weeding and spraying of pesticides and might be the possible reason for nonadoption.

\section{Water Management}

It could be seen from the table that majority of the jasmine growers (81.67 \%), had adopted proper water management practices on a weekly interval basis for cultivation. Only 18.33 $\%$ irrigated the field once in two weeks. The primary source of irrigation in the study area is through open well, bore well and ponds. Underground water is saline in nature. Further, the predominance of Ramanathapuram local variety which grows well in saline water, might also be a possible reason for this.

\section{Integrated Nutrient Management}

From the table, it could be further inferred that more than two-fifths $(43.33 \%)$ of the jasmine growers had applied $10 \mathrm{~kg}$ of FYM per plant and 90.00 per cent of the respondents applied NPK at 60:120:120 g per plant. 100 per cent of the respondents applied FYM manure after pruning followed by 80.83 per cent of the respondents during June - July.

Most of the respondents would have realized the importance of application of fertilizers and have applied right the dose at right time in two splits. The reason for 100 per cent application of manures after pruning is that the respondents are well aware of applying nutrients after pruning to get high production of jasmine

\section{Weeding and Pruning}

It could be observed from the table that most (91.66 \%) of the jasmine growers were found to take up weeding in their field. General manual weeding was done by the farmers. No special implements were used for weeding in the main fields.

Majority (87.80\%) of the respondents adopted proper pruning time during the last week of November. 
The farmers felt that the weeding and removal of dead branches are essential to get good yield. This could be the possible reason for high adoption level.

Further, it could be understood that one- third $(35.83 \%)$ of the jasmine growers adopted pruning height of 50 $\mathrm{cm}$ and nearly two thirds (64.17\%) of the respondents prune their plants according to their convenience. Generally the growers allow the goats to browse their jasmine fields with the belief of getting more production. This might be the possible reason for low adoption of pruning height.

\section{Plant Protection Measures}

Integrated crop protection management for disease incidence was followed by majority of the jasmine growers in the study area. It was observed that 100 per cent of the respondents had adopted the recommended control measures for bud worms \& blossom midges.

Farmers who were aware of the recommended pesticides for budworms, blossom midge and red spider mite have used pesticides to control the pests. In the case of nematode, most of the respondents $(85.33 \%)$ had not adopted proper control measures followed by root rot (42.50\%). Lack of awareness on nematode and root rot management might be the possible reason for low adoption level.

\section{Harvest}

It was observed that all respondents harvested jasmine at fully developed unopened flower bud stage in the morning. Less damage of flowers and more fragrance and high marketing value could be the possible reasons for this adoption behaviour.

\section{CONCLUSION}

The analysis of extent of adoption indicated that 100 percent of the jasmine growers had adopted Ramanathapuram local variety, because of prevailing climatic condition, soil type (red soil) and saline water in Vallioor block compared to other blocks. Apart from that Ramanathapuram local is one of the ruling variety of jasmine in Tamil Nadu known for its high fragrance and thick petals. Majority of the farmers had adopted pest management practices for blossom midge and bud worm, time of harvest and application of manure and fertilizer after pruning. Farmers who were aware of the recommended pesticides for budworms, blossom midge and red spider mite have used pesticides to control the pests. Further, realizing the importance of application of fertilizers they have applied right dose at right time in two splits. The reason for 100 per cent application of manures after pruning is that the respondents are well aware of the fact that applying nutrients after pruning world result in high production of jasmine. 
The results of the study had indicated that low adoption was noticed in management of nematode infestation and root rot disease due to lack of awareness and poor knowledge on these technologies. The extension officials and scientists may provide adequate awareness and knowledge through capacity building.

\section{REFERENCES}

Jaisridhar, P. (2009) Adoption and Marketing Behaviour of Maize Growers. Unpublished M.Sc.(Ag.) Thesis, Agricultural College and Research Institute, TNAU, Coimbatore.

Sangeetha,S. (2009) Study on Factors Influencing the Adoption of Precision Farming Technologies in Tomato Cultivation. Unpublished M.Sc.(Ag.) Thesis, Agricultural College and Research Institute. TNAU, Coimbatore.

Sathyachitradevi, M. (2006). Spread and Acceptance of Low Cost Technologies of Major Crops by Resources Poor Farmers. Unpublished M.Sc.(Ag.) Thesis, Agricultural College and Research Institute. TNAU, Coimbatore.
Senthil,A. (2009). An Analysis on Crop Insurance Scheme Among Paddy Farmers of Cuddalore District.Unpublished M.Sc.(Ag.) Thesis, Agricultural College and Research Institute. TNAU. Madurai.

Shanmugachitra,P. (2007). A Comparative Study of Knowledge and Adoption of Progressive and Less Progressive Sericulturalists in Tamil Nadu. Unpublished M.Sc.(Ag.) Thesis, Agricultural College and Research Institute. TNAU, Coimbatore.

Shrivastava,K.K., M.S. Trivedi \& M.L. Lakhera,M.L. (2002) Knowledge and Adoption Behaviour of Chilli Growers. Agricultural Extension Review, 14(4), 22-25.

Sivashankar, N \& Shashidhar, K.K (2011) Adoption behavior of Jasmine cultivation in Bellary district. Indian Research Journal of Extension Education 11(1), 23-26

Yavana Priya, D. Ponnusamy, K.A. \& Venkatapirabu, J. (2014) Adoption level of farmers on maize cultivation practices. Journal of Extension Education. 26(4) 